Vol. 8 No. 4 Desember 2019

E-ISSN: 2502-3101 P-ISSN: 2302-528x

http: //ojs.unud.ac.id/index.php/jmhu

\title{
Pengantar mengenai Hegemoni dan Hukum: Menyoal Kembali Bekerjanya Hukum di Masyarakat
}

\author{
Ricca Anggraeni1 ${ }^{1}$, Endra Wijaya ${ }^{2}$
}

${ }^{1}$ Program Doktor Ilmu Hukum Universitas Diponegoro, Semarang e-mail: cha2_khan@yahoo.com ${ }^{2}$ Fakultas Hukum Universitas Pancasila, Jakarta e-mail: endra.wijaya333@yahoo.co.id

\begin{tabular}{l}
\hline Info Artikel \\
\hline Masuk: 4 Maret 2019 \\
Diterima: 12 September 2019 \\
Terbit: 31 Desember 2019 \\
Keywords: \\
Authority; Hegemony; The \\
Binding Force of Law \\
\\
\\
Kata kunci: \\
Hegemoni; Kekuatan Mengikat \\
Hukum; Otoritas \\
Corresponding Author: \\
Endra Wijaya, email: \\
endra.wijaya333@yahoo.co.id \\
DOI: \\
10.24843/JMHU.2019.v08.i04.p05 \\
\hline
\end{tabular}

\begin{abstract}
Gramsci's concept of hegemony tries to explain how modern capitalist society has been organized. Although he did not explain about law particularly, but his study on hegemony is relevant and usefull to the study of law untill now. This paper focuses on how to understand the concept of hegemony and use it in field of the study of law. To examine the focus of this study, conceptual approach is used, and some points of argumentations in this study are based on several scholars' opinions related to concept of hegemony. This study concludes that hegemony could be understood as the way to how certain social group obtains its authority persuasively, and then leads others to give its consensus to hegemonic social group. This point could help to understand about the working and binding force of authority and law in the society. Besides that, the concept of hegemony could also become a kind of tool in understanding the dynamic of law, such as how could law becomes a tool of social engineering, or how, at the end, law is obeyed by the society.
\end{abstract}

\begin{tabular}{l}
\hline Abstrak \\
\hline Konsep hegemoni dari Gramsci berupaya menjelaskan bagaimana \\
masyarakat pada tahap kapitalis modern diorganisasikan. \\
Gramsci memang tidak secara khusus membahas persoalan \\
hukum, namun kajian hegemoninya ternyata relevan juga bagi \\
kajian di bidang hukum. Tujuan kajian atau pembahasan dalam \\
artikel ini diarahkan kepada persoalan memahami konsep \\
hegemoni, dan kemudian, bagaimanakah hegemoni ini, sebagai \\
sebuah konsep atau teori, dapat berguna di dalam kajian bidang \\
hukum. Pembahasan kedua hal tersebut menggunakan metode \\
pendekatan konseptual, dengan bersandar pada beberapa \\
pendapat sarjana. Kajian ini menyimpulkan bahwa hegemoni \\
dapat dipahami sebagai cara bagaimana suatu kelompok sosial \\
memperoleh pengaruh (kekuasaan) melalui cara-cara yang lebih \\
persuasif, dengan menggiring kelompok sosial lain (yang \\
dikuasai) untuk memberikan persetujuannya (konsensus) kepada \\
kelompok sosial yang menguasai. Poin ini bisa membantu untuk \\
memahami otoritas dan hukum yang bekerja serta mengikat \\
masyarakat. Selain itu, hegemoni dapat pula digunakan sebagai \\
alat bantu dalam memahami fenomena yang terjadi dalam bidang \\
hukum, seperti bagaimana hukum itu dapat berperan sebagai \\
sarana untuk mengubah masyarakat, atau bagaimana hukum itu \\
pada akhirnya dipatuhi oleh masyarakat.
\end{tabular}




\section{Pendahuluan}

Terminologi "hegemoni" sebenarnya sudah bukan merupakan terminologi yang asing dalam bidang hukum. Walaupun apabila ditelusuri akar pemikirannya, hegemoni ini awalnya memang merupakan sesuatu yang berkaitan erat dengan bidang politik.

Kini, teori atau konsep hegemoni sudah cukup sering digunakan oleh para ahli hukum dalam karya tulis ilmiah yang mereka hasilkan. Sebagai contohnya, dapat dilihat pada tulisan-tulisan karya beberapa guru besar di bidang hukum, seperti F.X. Adji Samekto dari Fakultas Hukum Universitas Diponegoro, ${ }^{1}$ dan Hikmahanto Juwana dari Fakultas Hukum Universitas Indonesia. ${ }^{2}$

Dengan menggunakan pendekatan konsep hegemoni, Samekto pernah melakukan kajian terhadap keberadaan hukum yang diduga kuat telah menjadi penyangga bagi kepentingan pemegang kekuasaan ekonomi dan politik. Paparan yang diajukan oleh Samekto mengambil contoh bagaimana kelompok "Negara Utara" menciptakan serta mempertahankan hubungan hukum yang tidak seimbang dengan kelompok "Negara Dunia ke Tiga" dengan menggunakan instrumen hukum internasional, seperti ketentuan-ketentuan mengenai perlindungan hak milik intelektual dalam kerangka World Trade Organization (WTO). ${ }^{3}$ Contoh itu memperlihatkan bahwa hegemoni benarbenar telah menjadi sesuatu yang penting untuk dicermati serta menjadi perhatian pula dalam bidang hukum.

Secara umum, dapat dikatakan bahwa hegemoni memang berkaitan erat dengan permasalahan yang cenderung politis. Pendapat seperti itu tentu tidak dapat disalahkan, karena hegemoni pada awalnya memang dikaji oleh para pemikir dalam bidang politik, seperti misalnya yang telah dilakukan oleh Lenin dan Antonio Gramsci.

Gramsci membangun konsep mengenai hegemoni saat dirinya mengamati praktik politik di Italia pada sekitar kurun waktu setelah perang dunia pertama, dan Gramsci pada beberapa poin pengamatannya menyinggung pula persoalan hukum, walaupun mungkin tidak secara eksplisit. Salah satu di antaranya, dia menjelaskan bahwa hegemoni dapat dipahami sebagai wujud sistem kekuasaan yang berlandaskan pada konsensus yang dibentuk dan lalu diajarkan dalam entitas negara. Hegemoni juga mampu mengkonstruksi tuntutan elemen partikular menjadi universal. ${ }^{4}$ Dalam kaitannya dengan entitas hukum, Gramsci memaparkan bahwa hukum dapat menjadi "alat untuk mendidik" dari negara terhadap warga negaranya, agar negara dapat

1 Samekto, F.X. Adji. (2008). Justice not for All: Kritik terhadap Hukum Modern dalam Perspektif Studi Hukum Kritis. Yogyakarta: Genta Press.

2 Juwana, Hikmahanto. (2001). Hukum Internasional dalam Konflik Kepentingan Ekonomi Negara Berkembang dan Maju. Pidato Upacara Pengukuhan sebagai Guru Besar Tetap dalam Ilmu Hukum Internasional pada Fakultas Hukum Universitas Indonesia, Depok, 10 November; dan Juwana, Hikmahanto. (2010). Hukum Internasional dalam Perspektif Indonesia sebagai Negara Berkembang. Jakarta: Yarsif Watampone.

${ }^{3}$ Samekto, op.cit., h. 55-61.

${ }^{4}$ Hastuti, Oktania Tri, dan Donny Gahral Adian. (2013). Problem Subjek Hegemoni dalam Pemikiran Antonio Gramsci: Telaah Hegemoni Militer dalam Perpolitikan Indonesia. <http://lib.ui.ac.id/naskahringkas/2016-04/S53383-Oktania\%20Tri\%20Hastuti>, diakses pada tanggal 8 Oktober 2018, h. 3-4. 
bekerja mewujudkan kondisi-kondisi kehidupan tertentu yang diinginkan. ${ }^{5}$ Apabila dielaborasi dengan menghubungkan pada pendapatnya Hans Kelsen dapat dipahami bahwa hukum ialah keharusan (ought), bukan fakta (is), dan keharusan itu berada di luar sistem itu sendiri atau di luar relasi sebab akibat. Oleh karenanya, sesuatu yang bersifat "seharusnya" itu bisa menjadi norma jika memang dikehendaki secara bersama sebagai norma yang dipatuhi bersama, yang selanjutnya diwujudkan dalam bentuk ketentuan hukum yang mengikat. Inilah yang disebut dengan kesepakatan atau konsensus. ${ }^{6}$

Dengan demikian, hegemoni sebenarnya memiliki makna yang luas (universal atau menyeluruh), dan dapat digunakan dalam berbagai konteks. Dengan begitu, dapat terlihat bahwa hegemoni memang memiliki keterkaikan pula dengan bidang hukum dengan segala dinamikanya. Apabila memang dapat dianggap begitu penting bagi bidang hukum, lantas apakah yang sesungguhnya dimaksud dengan hegemoni itu? Kemudian, bagaimanakah hegemoni ini, sebagai sebuah konsep atau teori, dapat berguna di dalam kajian bidang hukum? Pokok permasalahan itulah yang akan menjadi fokus pembahasan dalam artikel ini. Dari pembahasan tersebut diharapkan akan diperoleh pemahaman yang relatif lebih luas mengenai hegemoni, khususnya dalam kerangka kajian bidang hukum.

Selain secara praktis akan menjawab beberapa pokok permasalahan tersebut, pembahasan artikel ini diharapkan juga akan dapat melengkapi (memperkaya) kajian yang telah dilakukan oleh para sarjana hukum sebelumnya mengenai atau yang berkaitan dengan persoalan hubungan antara hukum dan kekuasaan, seperti yang sudah dilakukan oleh Samekto. Melalui kajiannya tentang relasi antara hukum dan kekuasaan, Samekto menyimpulkan bahwa ada beberapa tipe dari relasi antara hukum dan kekuasaan, yaitu: pertama, tipe di mana hukum sekedar menjadi alat untuk melanggengkan kekuasaan, bahkan tidak peduli jika hukum tersebut ditegakkan secara manipulatif (tipe hukum represif atau repressive law); ke dua, tipe di mana hukum menjaga jarak dan netral (tidak berpihak) dari kepentingan-kepentingan politik (tipe hukum otonom atau autonomous law); dan ke tiga, tipe di mana hukum benar-benar bisa ditegakkan sehingga tercipta keadilan substantif. Pada tipe yang terakhir ini, hukum ditegakkan demi kepentingan masyarakat banyak (tipe hukum responsif atau responsive law yang sejalan dengan hukum progresif). ${ }^{7}$

Namun, apa yang masih menjadi "ruang kosong" yang belum dibahas melalui kajian Samekto tersebut ialah persoalan dinamika relasi antara kekuasaan, hukum, dan hegemoni, bahwa dia ternyata bisa menjadi alat untuk menjinakkan dan/atau sekaligus menggugah individu-individu di dalam suatu bangunan sistem hukum. Celah itulah yang coba dibahas oleh kajian mengenai hegemoni dan hukum ini.

Selain itu, ada kajian yang menarik juga untuk dicermati dan dibandingkan dengan kajian dari peneliti ini, yaitu kajian dari Didiek R. Mawardi, yang menyoroti mengapa hukum belum berfungsi secara maksimal, dan bagaimana cara memaksimalkan fungsi

${ }^{5}$ Gramsci, Antonio. (2013). Prison Notebooks (Catatan-Catatan dari Penjara). Teguh Wahyu Utomo, penj. Yogyakarta: Pustaka Pelajar, h. 344.

6 Dimyati, Khudzaifah dan Kelik Wardiono. (2014). Paradigma Rasional dalam Ilmu Hukum: Basis Epistemologis Pure Theory of Law Hans Kelsen. Yogyakarta: Genta Publishing, h. 2.

7 Samekto, F.X. Adji. (2013). Relasi Hukum dengan Kekuasaan: Melihat Hukum dalam Perspektif Realitas. Jurnal Dinamika Hukum 13(1), h. 97. 
hukum itu dalam mewujudkan moralitas sebagai inti dari keadilan. Pembahasan yang dilakukan oleh Mawardi memang terkesan masih berada pada level "hukum yang seidealnya," dan untuk mencapai hal tersebut, Mawardi menawarkan untuk semakin mendorong dilakukannya upaya-upaya pemberdayaan serta partisipasi masyarakat, dan proses dialogis yang melibatkan baik masyarakat maupun penguasa. ${ }^{8}$

Namun, yang belum dikaji oleh Mawardi ialah persoalan fungsi hukum yang pada faktanya juga dapat menjadi salah satu alat untuk menundukkan atau menghegemoni masyarakat, di samping memaksa dan membuat tertib masyarakat sebagaimana fungsi-fungsi yang melekat pada hukum yang sudah sering dikaji oleh para sarjana. Pada poin itulah lantas terdapat perbedaan antara kajian yang sudah dilakukan oleh Mawardi dengan kajian dari peneliti kali ini.

\section{Metode Penulisan}

Kajian ini menggunakan metode penelitian hukum doktrinal, yang menurut Soetandyo Wignjosoebroto, merupakan metode penelitian yang dikembangkan, dikonsepkan, atau bersandarkan kepada doktrin yang dianut atau dipahami oleh pengonsep atau pengembangnya. ${ }^{9}$ Acuan konsep hegemoni yang dicermati dalam kajian ini terutama dari konsep hegemoni yang dikembangkan oleh Gramsci, sedangkan konsep hukumnya mengacu kepada konsep-konsep hukum dari beberapa sarjana.

Selanjutnya, metode pendekatan yang dipakai pada kajian ini ialah metode pendekatan konseptual. Informasi yang digunakan dalam kajian ini diperoleh dengan menggunakan metode penelusuran kepustakaan, dengan sebagian besar mengacu kepada bahan hukum sekunder, yang berupa karya tulis ilmiah dari para sarjana, namun pada beberapa poin pembahasan, bahan hukum primer juga tetap dicermati oleh peneliti. Informasi dari bahan-bahan hukum tersebut lalu dianalisis secara kualitatif.

\section{Hasil dan Pembahasan}

\subsection{Memahami Hegemoni}

Konsep hegemoni dapat ditelusuri akarnya mulai dari tahun 1920-an dan 1930-an. Secara sederhana, konsep hegemoni pada awalnya bermakna kepemimpinan moral serta filosofi, di mana kepemimpinan diperoleh melalui persetujuan yang aktif kelompok-kelompok utama di dalam masyarakat. ${ }^{10}$ Ernesto Laclau dan Chantal Mouffe memaparkan bahwa "Some Aspects of the Southern Question" tahun 1926 menjadi karya pertama Gramsci yang memuat konsep hegemoni. ${ }^{11}$ Namun, Gramsci

\footnotetext{
8 Mawardi, Didiek R. (2015). Fungsi Hukum dalam Kehidupan Masyarakat. Jurnal MasalahMasalah Hukum 44(3), h. 276 dan 281.

9 Wignjosoebroto, Soetandyo. (2002). Hukum: Paradigma, Metode, dan Dinamika Masalah. Jakarta: Lembaga Studi dan Advokasi Masyarakat (ELSAM) dan Perkumpulan untuk Pembaruan Hukum Berbasis Masyarakat dan Ekologi (HUMA), h. 147.

10 Bocock, Robert. (2007). Pengantar Komprehensif untuk Memahami Hegemoni. Bandung: Jalasutra, h. 1 .

${ }^{11}$ Laclau, Ernesto dan Chantal Mouffe. (2008). Hegemoni dan Strategi Sosialis: Posmarxisme dan Gerakan Sosial Baru. Yogyakarta: Resist Book, h. 96; Gündoğan, Ercan. (2008). Conceptions of
} 
sendiri mengembangkan konsepnya itu dari pemikiran-pemikiran Karl Marx sebelumnya mengenai kelas yang berkuasa. ${ }^{12}$

Hegemoni sebagai suatu proses, melibatkan upaya memenangkan dan memenangkan kembali secara berkesinambungan atau berkelanjutan kesepakatan di kalangan mayoritas terhadap sistem yang menempatkan mereka sebagai subordinat. ${ }^{13}$ "Pemegang kendali" dari proses itu ialah yang disebut sebagai kelas hegemonik.

Dalam melakukan proses memenangkan dan memenangkan kembali secara berkesinambungan atau berkelanjutan kesepakatan tersebut, maka salah satu strategi yang penting dalam hegemoni ialah mengkonstruksi "anggapan umum (common sense)."14 Namun kendalanya adalah bahwa pihak mayoritas yang subordinat tidak selamanya dapat mempertahankan kesepakatan yang telah dibuatnya. Pengalaman sosial sehari-hari yang dihadapi oleh mereka akan memberi pemahaman baru yang sangat mungkin bertentangan dengan anggapan umum yang telah dikonstruksi oleh kelas hegemonik. Akibatnya kemudian, pada diri pihak mayoritas yang subordinat dapat timbul sikap resistensi. ${ }^{15}$

Resistensi tersebut bisa saja diatasi, namun tidak pernah bisa dihilangkan. Jadi, tiaptiap kemenangan hegemonik, setiap kesepakatan yang diraih kelas hegemonik, pastilah tidak stabil. ${ }^{16}$ Oleh karena itu, di dalam konsep hegemoni proses kesepakatan yang diusahakan oleh kelas hegemonik memang harus dilakukan secara terusmenerus (berkesinambungan).

Dalam kajian hubungan internasional, gambaran tidak stabil seperti dimaksud di atas dapat dilihat contohnya pada hubungan antara Amerika Serikat sebagai negara adidaya dengan negara besar lain, yaitu Cina, maupun organisasi internasional lainnya. Paparan dari Min-Hua Chiang mengungkapkan bahwa Amerika Serikat yang disebut-sebut sebagai negara hegemonikpun di era sekarang, setelah berakhirnya "perang dingin," harus menghadapi fakta bahwa hegemoninya dalam kondisi tidak stabil. Kini, Amerika Serikat sedang menghadapi menguatnya pengaruh Cina, walaupun memang hingga saat ini belum ada satu entitas, baik negara ataupun organisasi internasional, yang benar-benar bisa menggantikan "kepemimpinan yang mendunia" dari Amerika Serikat. ${ }^{17}$

Pembahasan mengenai konsep hegemoni yang cukup terkenal ialah sebagaimana yang dikembangkan oleh Gramsci, seorang marxis asal Italia. Gramsci memakai konsep hegemoni untuk memaparkan serta menganalisis bagaimana masyarakat-masyarakat kapitalis modern diorganisasikan, atau dimaksudkan untuk diorganisasikan, pada

Hegemony in Antonio Gramsci's Southern Question and the Prison Notebooks. New Proposals: Journal of Marxism and Interdisciplinary Inquiry 2(1), h. 46.

12 Stoddart, Mark C.J. (2007). Ideology, Hegemony, Discourse: A Critical Review of Theories of Knowledge and Power. Social Thought and Research 28, h. 200-202; Boothman, Derek. (2008). The Sources for Gramsci's Concept of Hegemony. Rethinking Marxism 20(2), h. 201-202.

13 John Fiske, John. (2007). Cultural and Communication Studies: Sebuah Pengantar Paling Komprehensif. Bandung: Jalasutra, h. 243.

$14 \mathrm{Ibid}$.

15 Ibid., h. 245.

16 Ibid., h. 243.

17 Chiang, Min-Hua. (2015). The US Hegemony, East Asia and Global Governance. Bandung: Journal of the Global South 2(1), h. 12. 
masa lalu dan masa kini. Untuk hal itu, dia menjadikan peran kaum borjuis di Inggris, Prancis dan Italia sebagai objek penelitiannya mengenai hegemoni. ${ }^{18}$

Menurut Perry Anderson, terdapat 3 (tiga) model yang berbeda yang digunakan oleh Gramsci dalam karyanya The Prison Notebooks, yaitu: ${ }^{19}$

1. Dalam makna kepemimpinan budaya serta moral, hegemoni dipandang sebagai sesuatu yang diterapkan dalam masyarakat sipil. Keberadaan negara dilihat sebagai lokasi tempat beradanya kekuasaan koersif dalam bentuk polisi dan militer, serta ekonomi adalah sebagai lokasi dari beragam bidang pekerjaan, hal-hal yang berkaitan dengan uang tunai dan kontrol moneter. Dari model pertama ini dapat ditafsirkan, bahwa Gramsci mengungkapkan adanya 3 (tiga) wilayah (bidang atau lokasi) penting yang masing-masing memiliki fungsi berbeda-beda, yaitu masyarakat sipil, negara, dan ekonomi. Dari ketiga wilayah itu, maka wilayah masyarakat sipil adalah tempat di mana hegemoni beroperasi.

2. Hegemoni dipandang sebagai sesuatu yang dijalankan dalam negara serta dalam masyarakat sipil. Di sini berati hanya ada 2 (dua) wilayah, yaitu negara serta masyarakat sipil, dan hegemoni beroperasi pada kedua wilayah itu.

3. Tidak ada pembedaan lagi antara entitas negara dengan masyarakat sipil. Dan hegemoni telah beroperasi pada seluruh wilayah yang ada dalam negara.

Ketiga model di atas sebenarnya merupakan penjelasan mengenai perbedaan antara negara dengan masyarakat sipil dalam kaitannya dengan beroperasinya hegemoni. Pendapat Anderson itu ditanggapi oleh Robert Bocock sebagai pendapat yang kurang memadai, karena sebenarnya justru konsep hegemoni dari Gramscilah yang mampu menganalisis secara lebih lengkap, mengingat konsep hegemoni dari Gramsci tidak terjebak pada pendekatan determinisme ekonomi. Konsep hegemoni dari Gramsci dibangun di atas landasan 3 (tiga) unsur, yaitu perekonomian, negara, dan masyarakat. Ketiganya saling berhubungan serta mempengaruhi, dan lembaga hukum, menjadi salah satu unsur di dalam unsur negara tersebut. ${ }^{20}$

Sebelum Gramsci, sebenarnya telah ada beberapa pemikir lainnya yang mengembangkan konsep hegemoni, yaitu di antaranya Plekhanov pada tahun 1885 dan Lenin pada tahun 1920, keduanya ialah marxis asal Rusia.

Plekhanov mengembangkan konsep hegemoni dalam rangka menggulingkan Tsar. Hegemoni, menurut Plekhanov, merupakan suatu bentuk kepemimpinan yang harus diciptakan oleh kaum proletar di dalam suatu aliansi yang terdiri dari kaum proletar dan kelompok lain di luar kaum proletar, seperti kritikus borjuis, petani serta intelektual yang mempunyai tuuan sama untuk mengakhiri kekuasaan Tsar. ${ }^{21}$

Setelah Plekhanov, terdapat Lenin yang juga mengembangkan konsep hegemoni. Dalam konsepnya mengenai hegemoni, Lenin menekankan arti penting peran kepemimpinan teoretis. Menurut Lenin, teori adalah sesuatu yang penting jika hendak meningkatkan kesadaran serikat buruh (kaum proletar) yang berada di dalam keadaan

\footnotetext{
18 Bocock, op.cit., h. 25.

19 Ibid., h. 27-28.

20 Iklilah Muzayyanah Dini Fariyah. (2011). Hegemoni Antonio Gramsci: Sejarah dan Perkembangannya dalam Ranah Antropologi. Jurnal Antropologi Indonesia 32(2), h. 104-105.

21 Bocock, op.cit., h. 22.
} 
diperbudak oleh kaum borjuis. ${ }^{22}$ Dalam usahanya mempercepat revolusi Rusia, Lenin mengamati dan menyimpulkan bahwa saat dibiarkan mengurus sendiri, kelas buruh cenderung hanya mencapai kesadaran serta memperjuangkan keadaan yang lebih baik dalam sistem yang telah ada (mengikuti jalur yang telah dibentuk oleh pihak penguasa). Untuk mewujudkan perubahan revolusioner, dia berpendapat bahwa kaum Bolshevik harus menduduki posisi hegemonik dalam perlawanan menentang rezim Tsar yang sedang berkuasa. Hal ini artinya bukan saja memberdayakan berbagai serikat buruh yang ada untuk menyatukan semua kelas buruh, tapi juga harus melibatkan semua "strata oposisi" (elemen lain di luar kelas buruh) di dalam masyarakat ke dalam gerakan penumbangan rezim Tsar. ${ }^{23}$

Namun, dalam periode setelah revolusi, model hubungannya berganti. Lenin mengajukan argumentasi bahwa upaya-upaya mendesak yang diperlukan untuk membangun hegemoni proletariat ialah: pertama, kaum proletar (kelas buruh) perkotaan harus membina serta menjaga aliansinya dengan kaum tani pedesaan (bagian terbesar penduduk Rusia) untuk mempertahankan kepemimpinan nasional, dan ke dua, keterampilan kaum kapitalis lama harus dapat dimanfaatkan, dengan memaksa mereka untuk secara efektif mengurus industri-industri negara. Kedua proses kepemimpinan ini yang dilakukan melalui konsensus dan penggunaan paksaan, dalam pengembangan hegemoni, akan memainkan peran yang penting dalam pembentukan teori hegemoni dari Gramsci. ${ }^{24}$

Kembali ke Gramsci, dalam menjelaskan konsep hegemoninya, dia juga menjelaskan beberapa istilah kunci lainnya yang apabila tidak dipahami dengan benar akan dapat menimbulkan tumpang tindih (kekeliruan) pemahaman. Istilah-istilah kunci itu ialah "dominasi," dan "kepemimpinan intelektual serta moral." Keduanya berkaitan erat dengan wujud (bentuk) supremasi yang dilakukan oleh sebuah kelompok sosial.

Gramsci menjelaskan bahwa supremasi sebuah kelompok sosial dapat berwujud sebagai: dominasi, dan kepemimpinan intelektual serta moral. ${ }^{25}$ Dominasi ialah wujud bagaimana sebuah kelompok sosial memperoleh supremasi (keunggulannya) melalui penggunaan paksaan (coercion). Sedangkan kepemimpinan intelektual serta moral merupakan cara bagaimana kelompok sosial itu memperoleh supremasi melalui caracara yang lebih persuasif, dengan menggiring kelompok sosial lain (yang dikuasai) untuk memberikan persetujuannya (konsensus) kepada kelompok sosial yang menguasai. Penggunaan cara-cara yang persuasif inilah yang disebut dengan hegemoni. ${ }^{26}$

Jika paparan di atas dibawa ke dalam cakupan negara secara umum, maka baik dominasi maupun hegemoni keduanya telah saling berinteraksi di dalam organisasi negara, sehingga pada akhirnya negara itu sendiri dapatlah dikatakan sebagai

\footnotetext{
22 Ibid., h. 23.

${ }^{23}$ Brown, Trent. (2009). Gramsci and Hegemony. Links International Journal of Socialist Renewal. $<$ http://links.org.au/node/1260>, diakses pada tanggal 13 Oktober 2018.

${ }^{24}$ Ibid.

25 Pozzolini, A. (2006). Pijar-Pijar Pemikiran Gramsci. Eko P.D., penj. Yogyakarta: Resist Book, h. 79-80.

${ }^{26}$ Ibid.
} 
perwujudan dari "hegemoni yang dilindungi oleh senjata pemaksa (hegemony protected by the armour of coersion)." 27

Menurut Gramsci, hegemoni bukanlah merupakan praktik kekuasaan yang sifatnya sekali selesai (tuntas). Hegemoni merupakan praktik yang berlangsung secara terusmenerus, yaitu dijalankan mulai dari sebelum sebuah kelompok sosial merebut kekuasaan sampai dengan setelah kekuasaan itu berada di dalam genggamannya. Setelah kekuasaan diraih oleh sebuah kelompok sosial, maka dia tetap harus terus menjalankan hegemoninya untuk melestarikan (mempertahankan) kekuasaannya. ${ }^{28}$

Lebih lanjut, esensi konsep hegemoni dikembangkan lagi oleh Louis Althusser. Althusser menjelaskan bahwa kekuatan negara itu ditopang oleh struktur yang represif dan yang ideologis. Kekuatan negara dilestarikan melalui aparatur negara represif, yaitu struktur yang terdiri dari unsur pihak militer, kepolisian, hukum (peraturan), pengadilan, dan penjara. ${ }^{29}$ Unsur-unsur inilah yang pada pendapatnya Gramsci disebut sebagai "senjata pemaksa" yang terdapat di dalam negara sebagai sebuah "hegemony protected by the armour of coersion."

Selain struktur represif, kekuatan negara juga dilestarikan melalui cara yang lebih halus melalui perangkat aparatur negara ideologis. ${ }^{30}$ Struktur ideologis bekerja dengan cara mengamankan kesepakatan internal warganya ("memagari" kesadaran dan kepatuhan warga) melalui instrumen yang berwujud partai politik, sistem pendidikan (sekolah dan perguruan tinggi), lembaga keagamaan, seni, dan media massa. Semua instrumen itu berfungsi dalam menanamkan ideologi (sejumlah nilai, gagasan, keyakinan, dan sikap) yang sesuai dengan tujuan negara serta status quo politik. ${ }^{31}$

\subsection{Hegemoni dan Hukum}

Setelah penjelasan mengenai konsep hegemoni diberikan, pembahasan berikutnya ialah mengenai keterkaitan hegemoni itu dengan hukum. Pintu masuk untuk keperluan pembahasan itu ialah melalui pemaparan mengenai persoalan fungsi/peranan hukum, terutama dalam kaitannya dengan hubungan antara negara/penguasa/pemerintah dengan warganya (rakyat yang diperintah).

Gramsci, yang sering disebut sebagai salah satu penggagas teori hegemoni, hampir tidak pernah menulis khusus mengenai hukum dalam karyanya Prison Notebooks, tapi, sebagaimana paparan dari Douglas Litowitz, ternyata ada sedikit penjelasan dari Gramsci yang justru dapat mengantarkan memahami persoalan dualisme status dari hukum, sesuai dengan keberadaan 2 (dua) sumbu dari kekuasaan (power), yaitu paksaan secara fisik dan hegemoni. Atau dengan kata lain, hukum itu memang

\footnotetext{
27 Gramsci, op.cit., h. 17 dan 367; dan Simon, Roger. (1999). Gagasan-Gagasan Politik Gramsci. Kamdani dan Imam Baehaqi, penj. Yogyakarta: Insist Press dan Pustaka Pelajar, h. 107-108.

28 Pozzolini, op.cit., h. 80.

${ }^{29}$ Althusser, Louis. (2004). Tentang Ideologi: Marxisme Strukturalis, Psikoanalisis, Cultural Studies [Essays on Ideology]. Bandung: Jalasutra, h. 19-24; Barry, Peter. (2010). Beginning Theory. Yogyakarta: Jalasutra, h. 192.

${ }^{30}$ Althusser, op.cit., h. 19-24.

${ }^{31}$ Barry, op.cit., h. 192.
} 
memiliki 2 (dua) sisi sekaligus, yaitu bersifat memaksa dan konstitutif (repressive and constitutive). ${ }^{32}$

Menurut Litowitz, aspek yang bersifat memaksa dari hukum dapat dilihat, antara lain, dari kehadiran sosok petugas kepolisian, penjara, dan termasuk lembaga pengadilan yang dipersenjatai dengan kekuasaan untuk menyita atau menjatuhkan hukuman, yang semuanya diperlukan untuk memperbaiki keadaan (ketertiban) saat terjadi konflik (keadaan tidak tertib) di masyarakat. ${ }^{33}$

Lebih lanjut Litowitz memaparkan pula, sedangkan di sisi lain, hukum juga memperlihatkan kemampuannya untuk melegitimasi atau menciptakan seperangkat lembaga serta praktik sosial yang diakui atau diperbolehkan oleh negara. Fungsi hukum seperti inilah yang oleh Gramsci disebut sebagai bentuk peran dari negara dalam legislasi yang bersifat "mendidik." Sifat mendidik ini sekaligus memperlihatkan peran yang dimainkan oleh hukum yang berfungsi tidak secara represif, namun tetap mengarahkan masyarakat agar menuju (mengikuti) apa-apa yang dianggap legal serta diakui oleh negara. ${ }^{34}$

Secara teoretis, negara merupakan entitas yang terdiri dari (dibentuk dengan) unsurunsur pemerintahan, kedaulatan, penduduk (warga negara), dan wilayah (teritorial). Pada teori hukum internasional, ditambahkan pula adanya unsur pengakuan dari negara lain sebagai salah satu syarat dari keberadaan negara. Hubungan yang terjadi di dalam negara itu, setidaknya dapat dipahami dalam beragam bentuk, yaitu: hubungan antarpenguasa, hubungan antara penguasa/pemerintah dan warga negara, serta hubungan antara sesama warga negara (antarindividu). ${ }^{35}$

Hubungan antara penguasa/pemerintah dan warga negaranya dapat berbentuk hubungan yang sifatnya melayani, seperti pelayanan publik (public service) yang diselenggarakan oleh pemerintah bagi warganya, atau dapat juga berbentuk hubungan yang sifatnya mengontrol warga negaranya. Sedangkan hubungan antara sesama warga negara, umumnya berupa hubungan keperdataan, seperti perjanjian antarindividu dalam bentuk jual beli atau sewa-menyewa.

Bentuk hubungan-hubungan tersebut jelas membutuhkan kehadiran perangkat hukum dengan beragam fungsi yang dimilikinya. ${ }^{36}$ Dan pada hubungan-hubungan itu, hukum dapat berfungsi, antara lain, sebagai:

Pertama, memberikan perlindungan hukum bagi setiap pihak yang terkait dengan hubungan tersebut, terutama apabila terjadi sengketa hukum. Atau dengan kata lain, hukum di sini fungsinya ialah sebagai sarana untuk menyelesaikan sengketa hukum, pelanggaran hukum, atau konflik kepentingan. ${ }^{37}$ Fungsi seperti itu dapat disebut juga

32 Litowitz, Douglas. (2000). Gramsci, Hegemony, and the Law. BYU L. Rev. 2000(2). $<$ https://digitalcommons.law.byu.edu/lawreview/vol2000/iss2/1>, h. 530.

33 Ibid.

${ }^{34}$ Ibid.; dan Gramsci, op.cit., h. 344.

${ }^{35}$ Soekanto, Soerjono dan Purnadi Purbacaraka. (1993). Sendi-Sendi Ilmu Hukum dan Tata Hukum. Bandung: Citra Aditya Bakti, h. 62.

36 Paparan mengenai macam-macam fungsi hukum yang cukup lengkap, antara lain, dapat dilihat pada kajian dari Mawardi, op.cit., h. 278-281; dan Yusuf, Asep Warlan. (2015). Hukum dan Keadilan. Padjadjaran Jurnal Ilmu Hukum 2(1), h. 7-8.

${ }^{37}$ Mertokusumo, Sudikno. (2010). Mengenal Hukum: Suatu Pengantar. Yogyakarta: Cahaya Atma Pustaka, h. 38-39. 
sebagai fungsi integrasi dari hukum. ${ }^{38}$ Dalam hal pengembanan fungsi integratif ini, para penegak hukum mempunyai kedudukan penting karena dia berperan untuk mewujudkan (menegakkan) keadilan, di samping ideologi yang menjadi dasar legitimasi, dan isi sanksi serta prosedur bagaimana memproses (menjatuhkan) sanksi tersebut. ${ }^{39}$

Fungsi integrasi dari hukum bisa memperlihatkan bahwa hukum itu dapat dimasukkan ke dalam kategori aparatur negara represif (mengikuti pembagian yang disusun oleh Althusser). Dikatakan bersifat represif karena hukum ini bekerja memaksa melalui ancaman sanksi agar setiap pihak mematuhi norma-norma yang telah ditetapkan sebagai hukum. Sanksi itulah yang juga menjadi ciri khas dari norma hukum ketika dia dibandingkan dengan norma lainnya, seperti norma agama, kesusilaan, dan kesopanan. ${ }^{40}$ Dengan demikian, setiap pelanggaran hukum akan dikenakan proses hukum yang dapat berakhir pada penjatuhan sanksi.

Sifat represif hukum juga dapat dilihat pada kenyataan bahwa hukum itu tetap dapat bekerja di masyarakat walaupun tanpa kesediaan dari warga negara untuk sukarela menaatinya. Untuk hal itu, Joseph S. Roucek, sebagaimana dikutip oleh Soetandyo Wignjosoebroto, menjelaskan bahwa pada hakikatnya hukum merupakan instrumen kontrol. Sebagai instrumen kontrol, hukum ditandai dengan sifatnya yang formal, tidak pernah berharap kesediaan warga untuk secara suka dan rela menaatinya, dan pelaksanaannya selalu disertai ancaman sanksi. ${ }^{41}$

Akan menjadi semakin jelas lagi apabila sifat represif dari hukum tersebut dilihat pada sistem hukum pidana yang di dalamnya jelas terdapat unsur sanksi fisik yang mengancam. Dengan asasnya ultimum remedium, hukum pidana mengisyaratkan bahwa norma-norma hukumnya akan menjadi alat pemaksa terakhir bagi setiap pelanggaran hukum, dan pelakunya akan menerima sanksi, melalui putusan pengadilan, yang dapat berupa hukuman penjara, bahkan hukuman mati. ${ }^{42}$

Namun, model pendekatan "semacam top-down" seperti paparan di atas tidak lantas bisa menjadikan semua hukum berjalan dengan efektif di masyarakat. Pendekatan topdown tidak dapat diterapkan secara sama dan seragam bagi semua bidang hukum. Adakalanya juga bahwa hukum itu memerlukan masukan lain di luar strukturnya yang resmi, formal, dan yang terkesan kaku tersebut. Asumsinya ialah, sebagaimana paparan dari Ugo Mattei, bahwa kekuatan itu, termasuk kekuatan yang berwujud norma hukum, tidak pernah bisa mencukupi atau memenuhi kebutuhannya sendiri dalam penerapannya, melainkan dia selalu tetap membutuhkan sedikit banyak

38 Susanto, Anthon F. (2004). Wajah Peradilan Kita: Konstruksi Sosial tentang Penyimpangan, Mekanisme Kontrol dan Akuntabilitas Peradilan Pidana. Bandung: Refika Aditama, h. 68.

${ }^{39}$ Pendapat Berger dan Ronny Hanitijo Soemitro sebagaimana dikutip dalam Rahayu, Derita Prapti. (2014). Budaya Hukum Pancasila. Yogyakarta: Thafa Media, h. 23; dan lihat juga Ernas, Saidin, dan Zuly Qodir. (2013). Agama dan Budaya dalam Integrasi Sosial (Belajar dari Pengalaman Masyarakat Fakfak di Propinsi Papua Barat). Jurnal Pemikiran Sosiologi 2(2), h. 45.

${ }^{40}$ Mertokusumo, op.cit., h. 22.

41 Wignjosoebroto, Soetandyo. (2002). Hukum dalam Masyarakat: Perkembangan dan Masalah, sebuah Pengantar ke Arah Kajian Sosiologi Hukum. Malang: Bayumedia, h. 135.

${ }^{42}$ Kanter, E.Y. dan S.R. Sianturi. (2002) Asas-Asas Hukum Pidana di Indonesia dan Penerapannya. Jakarta: Storia Grafika, h. 31. 
perluasan kesepakatan yang terlembagakan secara baik dalam menerima dirinya selaku norma hukum yang akan diterapkan di tengah-tengah masyarakat. ${ }^{43}$

Bagaimana akhirnya Undang-Undang Nomor 17 Tahun 2012 tentang Perkoperasian dibatalkan oleh Mahkamah Konstitusi merupakan suatu contoh menarik yang memperlihatkan bahwa pada akhirnya persoalan kesepakatan dan penerimaan yang meluas serta melembaga ikut menentukan berlaku atau tidak berlakunya suatu produk hukum. Dalam proses pembatalan Undang-Undang Nomor 17 Tahun 2012 tentang Perkoperasian, tampak sekali terjadi semacam sinergi serta perluasan kesepakatan yang melembaga antara masyarakat, organisasi perkoperasian, akademisi, dan Mahkamah Konstitusi yang berujung pada dibatalkannya undang-undang tersebut.

Ke dua, dalam kaitannya dengan perubahan sosial, hukum bisa berfungsi sebagai sarana untuk mengubah masyarakat. Soerjono Soekanto memaparkan konsep social engineering (social planning), sebagaimana dipelopori oleh Roscoe Pound, sebagai "caracara untuk mempengaruhi masyarakat dengan sistem yang teratur dan direncanakan terlebih dahulu."44 Di dalam social engineering itu, hukum bisa menjalankan pengaruhnya, baik langsung maupun tidak langsung, untuk mendorong atau mengupayakan terjadinya perubahan sosial. 45

Subjek yang berperan penting sebagai "dalang" (perencana, pengendali, dan pengawas) dalam menggunakan hukum sebagai alat pada proses perubahan sosial adalah pihak yang disebut sebagai pelopor perubahan (agent of change). Pelopor perubahan itu ialah seseorang atau sekelompok orang yang memperoleh kepercayaan dari masyarakat untuk menjadi pemimpin. ${ }^{46}$ Dalam konteks negara modern, sebagai salah satu contohnya, dia dapat berwujud pemerintah yang sedang berkuasa melalui saluran-saluran lembaga atau pejabat yang memiliki kewenangan untuk membentuk hukum, yang dalam konteks Indonesia ialah peraturan perundang-undangan.

Berdasarkan penjelasan Soekanto tersebut, apabila ingin melihat keterkaitan antara fungsi hukum sebagai sarana untuk mengubah masyarakat dengan hegemoni, maka fokusnya (penekanannya) harus lebih diarahkan kepada unsur "mempengaruhi masyarakat" dan kehadiran subjek "pelopor perubahan (agent of change) yang dipercaya."

Dalam proses perubahan sosial, fungsi yang dijalankan oleh hukum sebenarnya lebih merupakan fungsi yang persuasif, karena diharapkan bisa mempengaruhi masyarakat untuk berperilaku sesuai dengan yang telah direncanakan dan dikehendaki oleh pelopor perubahan. Di sini hukum beroperasi tidak secara terang-terangan, sehingga secara perlahan-lahan, secara sadar atau tidak, akan mempengaruhi perilaku individuinvidu di dalam masyarakat. Fungsi inilah yang sangat bermain di dalam peraturan perundang-undangan. Pelopor perubahan, dengan demikian, memiliki monopoli di

\footnotetext{
${ }^{43}$ Mattei, Ugo. (2003). A Theory of Imperial Law: A Study on U.S. Hegemony and the Latin Resistance. Indiana Journal of Global Legal Studies 10(1). $<$ http:// www.repository.law.indiana.edu/ijgls/vol10/iss1/14>, h. 389.

${ }^{44}$ Latipulhayat, Atip. (2014). Roscoe Pound. Padjadjaran Jurnal Ilmu Hukum 1(2), h. 418-420; Soekanto, Soerjono. (2003). Pokok-Pokok Sosiologi Hukum. Jakarta: PT. RajaGrafindo Persada, h. 122.

${ }^{45} \mathrm{Ibid}$.

${ }^{46}$ Ibid.
} 
dalam pembentukan norma hukum untuk bisa mempengaruhi perilaku bahkan mengubah tatanan-tatanan sosial yang telah ada di masyarakat.

Praktik yang terjadi di dalam pembentukan peraturan perundang-undangan sangat menunjukkan besarnya hukum sebagai alat untuk melakukan perubahan sosial. Peraturan perundang-undangan yang dihasilkan selalu menjadi "penghalalan" bagi perilaku dan tindakan pemerintah bahkan masyarakat. Dengan demikian, perilaku dan tindakan itu tidak dapat terlepas dari apa yang sudah diperintahkan, diperbolehkan bahkan dilarang melalui norma-norma yuridis di dalam peraturan perundang-undangan. Meskipun, di dalam hasil pembentukan itu, hegemoni dari pemerintah yang berkuasa lebih kentara dibandingkan dengan kesepakatan ideal di antara rakyat melalui jalur partisipasinya, misalnya, pada Undang-Undang Nomor 7 Tahun 2004 tentang Sumber Daya Air yang telah dinyatakan inkonstitusional oleh Mahkamah Konstitusi, dan Undang-Undang Nomor 7 Tahun 2014 tentang Perdagangan yang tiba-tiba menjadikan pendidikan sebagai komoditi perdagangan. ${ }^{47}$

Struktur normatif yang terdapat di dalam diri manusia jelas memungkinkan hal tersebut di atas terjadi. Karena pada dasarnya, sebagaimana pendapat J. Blake dan K. Davis, ${ }^{48}$ pada diri pribadi manusia terdapat potensi untuk dapat mengubah perilakunya melalui serangkaian perubahan terencana di dalam wujud penggunaan kaedah-kaedah hukum (sebagai sarananya).

Dalam pembagian mengenai struktur penopang kekuatan negara dari Althusser, maka fungsi hukum dalam kaitannya dengan proses perubahan sosial dapat diposisikan ke dalam struktur yang ideologis. Dalam struktur yang ideologis, hukum lebih ditekankan perwujudannya ke dalam hal-hal yang tidak bersifat memaksa. Hukum

47 Undang-Undang Nomor 7 Tahun 2014 tentang Perdagangan merupakan undang-undang pertama yang dibuat oleh Indonesia yang mengatur tentang perdagangan secara keseluruhan, yang sebelumnya menginduk pada peraturan perundang-undangan warisan Pemerintah Belanda. Undang-undang ini juga dibuat untuk menyikapi perkembangan situasi perdagangan di era globalisasi, salah satunya ialah Masyarakat Ekonomi ASEAN (MEA). Namun alih-alih untuk itu, Undang-Undang Nomor 7 Tahun 2014 tentang Perdagangan telah meliberalisasi perdagangan termasuk berbagai jasa dan salah satunya ialah jasa pendidikan. Liberalisasi jasa pendidikan oleh Undang-Undang Nomor 7 Tahun 2014 tentang Perdagangan menunjukkan diusungnya sistem ekonomi kapitalisme di Indonesia. Padahal dalam Lampiran II Undang-Undang Nomor 12 Tahun 2011 tentang Pembentukan Peraturan Perundang-Undangan yang mengatur tentang teknik penyusunan peraturan perundangundangan, menyebutkan bahwa landasan filosofis yang terdapat dalam konsiderans mendeskripsikan bahwa peraturan yang dibentuk memperhatikan dengan cermat pandangan hidup, keinsafan dan cita hukum yang meliputi suasana kebatinan serta falsafah bangsa Indonesia yang bersumber dari Pancasila dan Pembukaan Undang-Undang Dasar Negara Republik Indonesia Tahun 1945. Artinya, Pancasila merupakan norma dasar negara (Grundnorm) sekaligus sebagai cita hukum Negara Indonesia yang menjadi acuan rancangan atau garis besar keyakinan secara normatif karena berfungsi sebagai pangkal, sumber bagi setiap hukum positif dan mengarahkan bangsa Indonesia menuju cita negara atau tujuan yang hendak dicapai. Untuk itulah, Pancasila pun disebut sebagai kaidah fundamental negara (Staatsfundamentalnorm). Anggraeni, Ricca. (2015). Mengungkap Kemampuan Cara Pembentukan Hukum Modifikasi dalam Mendukung Pembangunan Sistem Hukum Indonesia Berbasis Pancasila dan Menghadapi Tantangan di Era Global. Ujian Kualifikasi di Program Doktor Universitas Diponegoro, Semarang, 24 Juli.

${ }^{48}$ Soekanto, op.cit., h. 139. 
justru lebih dimaknai sebagai kesadaran atau budaya yang perlu ditanamkan ke dalam diri tiap individu sehingga pada akhirnya akan bermuara ke ketertiban masyarakat. Hanya sayangnya, di dalam praktik, ideologi di dalam pembentukan hukum untuk memenuhi fungsi sebagai perubahan sosial akan luntur ketika berhadapan dengan kepentingan-kepentingan ideologi yang dominan dalam pribadi si pembentuk hukum.

Pembentukan hukum dalam konteks undang-undang saat ini tunduk kepada UndangUndang Nomor 12 Tahun 2011 tentang Pembentukan Peraturan PerundangUndangan. Namun pada hasilnya, undang-undang yang terbentuk justru mengindikasikan diboncengi oleh kepentingan-kepentingan golongan tertentu, terutama ialah kepentingan pihak pemilik modal (kapitalis). Salah satu contohnya dapat dicermati dalam Undang-Undang Nomor 7 Tahun 2004 tentang Sumber Daya Air, dan Undang-Undang Nomor 17 Tahun 2012 tentang Perkoperasian yang akhirnya dibatalkan melalui proses judicial review oleh Mahkamah Konstitusi. Hampirlah serupa kisah Undang-Undang Nomor 17 Tahun 2012 tentang Perkoperasian, undang-undang ini dinyatakan oleh Mahkamah Konstitusi dalam pertimbangan putusannya tidak sesuai dengan hakikat susunan perekonomian sebagai usaha bersama serta berdasarkan prinsip kekeluargaan sebagaimana tercantum dalam Pasal 33 ayat (1) Undang-Undang Dasar Negara Republik Indonesia Tahun 1945. Pada UndangUndang Nomor 17 Tahun 2012 tentang Perkoperasian tersebut terkandung nilai-nilai individualistis dan liberal. ${ }^{49}$

Beberapa contoh tersebut, menjadi realitas yang menarik untuk mendeskripsikan bahwa produk undang-undang yang dihasilkan oleh pemerintah yang berkuasa ternyata masih berisi agenda-agenda yang tersembunyi dari pihak atau kelompok tertentu, sehingga memicu timbulnya penguasaan oleh sebagian pihak terhadap pihak lain.

Ke tiga, hukum juga dapat menjadi dasar legitimasi bagi hubungan-hubungan, baik antara penguasa/pemerintah dan warga negara, ataupun antara sesama warga negara. Fungsi hukum seperti itu merupakan salah satu fungsi hukum sebagai "pembuat norma yang memberikan peruntukan atau menentukan hubungan-hubungan."50

Dalam pandangan para marxis, fungsi hukum juga dipahami sebagai alat untuk melegitimasi serta menyelimuti hubungan atau relasi kekuatan yang sebenarnya timpang, yaitu relasi antara kelas kapitalis (yang menguasai kekuatan produksi) dengan kelas buruh, sehingga seolah-olah sah serta adil. Di sini dipahami bahwa hukum hanya berpura-pura menjadi instrumen yang netral. Padahal, sebenarnya hukum tersebut hanya membela kepentingan pihak penguasa. ${ }^{51}$ Jadi, hukum dalam pengertian ini memang cenderung negatif.

Berbeda dengan pandangan para marxis tersebut, sekadar perbandingan, aliran positivis dalam hukum justru menganggap hukum dapat membantu memudahkan hubungan antara individu. Untuk hal itu dapat disimak salah satunya dari pendapat H.L.A. Hart yang menjelaskan bahwa “... semua [hukum] itu menyediakan fasilitas

49 Nugraha, Rahadian Prima. (2017). Pembaharuan UU Perkoperasian Pasca Putusan Mahkamah Konstitusi Nomor 28/PUU-XI/2013. Jurnal Legislasi Indonesia 14(1), h. 34.

50 Rahardjo, Satjipto. (2009). Hukum dan Perubahan Sosial: Suatu Tinjauan Teoretis serta Pengalaman-Pengalaman di Indonesia. Yogyakarta: Genta Publishing, h. 111.

${ }^{51}$ Freeman, M.D.A. (1994). Lloyd's Introduction to Jurisprudence. London: Sweet and Maxwell Ltd., h. 857 dan 947. 
(kemudahan) bagi para individu untuk merealisasikan keinginan mereka, dengan memberikan kekuatan hukum kepada mereka untuk menciptakan struktur hak dan kewajiban dalam kerangka paksaan hukum, melalui prosedur tertentu dan bergantung pada kondisi tertentu... merupakan salah satu kontribusi besar dari hukum kepada kehidupan sosial..." 52

Terutama dalam kaitannya dengan keberadaan pihak penguasa/pemerintah, legitimasi mengisyaratkan bahwa hubungan yang terjadi mengandung unsur kemauan dan kepatuhan dari suatu pihak kepada pihak lainnya karena adanya hukum yang menjadi dasar kewenangan, ${ }^{53}$ dalam hal ini ialah dari pihak warga negara kepada pihak penguasa/pemerintah. Namun kepatuhan itu tidak secara tiba-tiba datangnya, dan bukan pula semata-mata hanya dikarenakan faktor penguasaan secara ekonomi, seperti yang dikemukakan dalam teori marxis klasik/ortodoks. Pihak-pihak yang patuh biasanya telah lebih dulu memiliki sistem nilai atau keyakinan yang ada pada dirinya sehingga membuat dirinya "secara sukarela (tidak merasa terpaksa)" bersedia mengakui pihak lain sebagai pihak wajar untuk dipatuhi.

Sistem nilai atau keyakinan yang pada akhirnya dapat membuat suatu pihak secara sukarela mengakui pihak lain itulah yang dimaksud dengan ideologi. Ideologi ini ditanamkan ke dalam diri warga negara (yang diperintah) oleh penguasa/pemerintah melalui proses yang disebut hegemoni, melalui lembaga-lembaga yang ada di tengahtengah masyarakat, seperti lembaga pendidikan dan media massa, serta dalam waktu yang relatif lama. ${ }^{54}$

Namun yang patut diingat ialah, bahwa proses penanaman ideologi melalui hegemoni tersebut tidak selamanya bermakna negatif. Hegemoni akan disebut sebagai sesuatu yang negatif, biasanya apabila dihubungkan dengan suatu keadaan warga negara yang tumpul daya kritisnya ketika berhadapan dengan penguasa/pemerintah. Pada masyarakat yang seperti itu, ideologi yang ditanamkan kepada mereka oleh penguasa/pemerintah adalah ideologi yang, menurut Marx, isinya merupakan "kesadaran palsu" yang mengarahkan masyarakat agar mengikuti kehendak dan tujuan penguasa/pemerintah. ${ }^{55}$

Tetapi di sisi lain, ada kalanya hegemoni justru bermakna positif, seperti dalam mendorong terciptanya keadaan yang tertib di masyarakat. Hal yang positif seperti itu dapat dilihat pada fungsi yang dijalankan oleh hukum pada perubahan sosial, yang telah dijelaskan sebelumnya. Berkaitan dengan hal tersebut, berbeda dengan Marx, Althusser malah berhasil melihat potensi positif dari ideologi yang disebarkan melalui hegemoni. Walaupun Althusser telah membangun kritiknya terhadap ideologi, tetapi dia tidak berniat menganjurkan manusia untuk membebaskan dirinya dari ideologi. Bagi Althusser, ideologi tetap memiliki sisi yang positif bagi manusia. ${ }^{56}$

Sejalan dengan penjelasan di atas, Trent Brown dalam paparannya mengenai pemikiran Gramsci dan hegemoni juga mengungkapkan "2 (dua) sisi wajah" dari hegemoni. Menurut Brown, yang patut diingat dan tidak boleh dilupakan ketika

${ }^{52}$ Hart, H.L.A. (2009). Konsep Hukum (The Concept of Law). Bandung: Nusa Media, h. 44.

${ }^{53}$ Logeman, J.H.A. (1975). Tentang Teori suatu Hukum Tata Negara Positif. Jakarta: Ichtiar BaruVan Hoeve, h. 7.

${ }^{54}$ Althusser, op.cit., h. 33-34.

55 Takwin, Bagus. (2009). Akar-Akar Ideologi. Yogyakarta: Jalasutra, h. 58-59.

56 Ibid., hlm. 86. 
membahas pengertian dari hegemoni dari Gramsci adalah bahwa dia tidak hanya menggunakan istilah hegemoni untuk mendeskripsikan aktivitas kelas penguasa, dia juga memakainya untuk menggambarkan pengaruh yang diberikan oleh kekuatankekuatan progresif. Dengan mengingat hal ini, maka dapat dilihat bahwa hegemoni seharusnya definisikan dan dipahami sebagai aktivitas yang dilakukan bukan saja oleh kelas penguasa, tetapi faktanya dia juga ialah proses di mana kelompok-kelompok sosial (secara lebih luas) berupaya memperoleh kekuasaan untuk memimpin, memperluas kekuasaan mereka, serta menjaganya secara berkesinambungan. ${ }^{57}$

Masih menurut Brown, dalam karya Gramsci dapat ditemukan perbedaan kualitatif antara pelaksanaan hegemoni oleh kelompok regresif dan otoriter di satu pihak, dan kelompok-kelompok sosial di pihak lainnya. Gramsci meyakini pula bahwa kebenaran tidak dapat diterapkan begitu saja dari atas ke bawah, tapi hanya melalui dialog yang konkret, persuasif, dan simpatik dengan rakyat. Jadi, hegemoni regresif memang melibatkan penerapan serangkaian nilai yang tidak ternegosiasikan kepada rakyat, terutama melalui paksaan (bersifat koersif) dan bahkan penipuan, sedangkan hegemoni progresif justru akan berkembang dengan kesepakatan (konsensus) dari masyarakat yang diraih secara demokratis. ${ }^{58}$ Atau, dalam kalimat lain yang lebih sederhana, dapat dikatakan bahwa hegemoni ini merupakan proses, yang dipahami sebagai upaya untuk mendorong tercapainya kesadaran kolektif.

Dari penjelasan Brown tersebut di atas, maka dapat juga dipahami bahwa adakalanya pada suatu "wilayah pertarungan" di dalamnya terdapat lebih dari satu kelompok yang mengupayakan hegemoni. Dalam konteks internasional, sebagai salah satu contoh, keadaan seperti itu dapat dilihat pada upaya-upaya dari Amerika Serikat dan Cina untuk saling meraih pengaruh dan kepemimpinan di wilayah Asia, terutama Asia Timur. Dan untuk upaya-upaya itu, alat yang digunakan ialah hubungan internasional dan hukum internasional, yang salah satunya mewujud dalam bentuk kesepakatan-kesepakatan serta organisasi-organisasi internasional kawasan (regional) Asia. Setidaknya begitulah yang tersirat dalam hasil kajian dari G. John Ikenberry mengenai dinamika perubahan dari hegemoni menuju ke upaya menyeimbangkan kekuatan antara Amerika Serikat dan Cina di Asia Timur. ${ }^{59}$

\section{Kesimpulan}

Berdasarkan pembahasan tersebut di atas, maka peneliti bisa menarik beberapa simpulan, yaitu: pertama, pada awalnya memang konsep hegemoni dikembangkan dalam bidang politik. Hegemoni dapat dipahami sebagai cara bagaimana suatu kelompok sosial memperoleh pengaruh (kekuasaan) melalui cara-cara yang lebih persuasif, dengan menggiring kelompok sosial lain (yang dikuasai) untuk memberikan persetujuannya (konsensus) kepada kelompok sosial yang menguasai. Poin ini dapat membantu untuk memahami perihal entitas otoritas dan hukum yang bekerja serta mengikat masyarakat.

\footnotetext{
57 Brown, loc.cit.

58 Ibid.

${ }^{59}$ Ikenberry, G. John. (2014). From Hegemony to the Balance of Power: The Rise of China and American Grand Strategy in East Asia. International Journal of Korean Unification Studies 23(2), h. 60-61.
} 
Ke dua, ternyata konsep hegemoni dapat pula digunakan sebagai alat bantu dalam memahami fenomena yang terjadi dalam bidang hukum, seperti bagaimana hukum itu dapat berperan sebagai sarana untuk mengubah masyarakat, atau bagaimana hukum itu pada akhirnya dipatuhi "secara sukarela" oleh masyarakat. Bahkan, konsep hegemoni dapat juga menjadi alat bantu untuk mempertanyakan kembali netralitas hukum, seperti yang selalu "didoktrinkan" selama ini.

\section{Ucapan Terima Kasih}

Peneliti menyampaikan terima kasih kepada: Rifkiyati Bachri dari Laboratorium Penelitian (Lab. I) Fakultas Hukum Universitas Pancasila atas informasi dan pendapatnya mengenai dinamika hukum koperasi di Indonesia, yang sempat disinggung dalam kajian ini.

\section{Daftar Pustaka}

\section{$\underline{\text { Buku }}$}

Althusser, Louis. (2004). Tentang Ideologi: Marxisme Strukturalis, Psikoanalisis, Cultural Studies [Essays on Ideology]. Bandung: Jalasutra.

Barry, Peter. (2010). Beginning Theory. Yogyakarta: Jalasutra.

Bocock, Robert. (2007). Pengantar Komprehensif untuk Memahami Hegemoni. Bandung: Jalasutra.

Dimyati, Khudzaifah dan Kelik Wardiono. (2014). Paradigma Rasional dalam Ilmu Hukum: Basis Epistemologis Pure Theory of Law Hans Kelsen. Yogyakarta: Genta Publishing.

Freeman, M.D.A. (1994). Lloyd's Introduction to Jurisprudence. London: Sweet and Maxwell Ltd.

Gramsci, Antonio. (2013). Prison Notebooks (Catatan-Catatan dari Penjara). Teguh Wahyu Utomo, penj. Yogyakarta: Pustaka Pelajar.

Hart, H.L.A. (2009). Konsep Hukum (The Concept of Law). Bandung: Nusa Media.

John Fiske, John. (2007). Cultural and Communication Studies: Sebuah Pengantar Paling Komprehensif. Bandung: Jalasutra.

Juwana, Hikmahanto. (2010). Hukum Internasional dalam Perspektif Indonesia sebagai Negara Berkembang. Jakarta: Yarsif Watampone.

Kanter, E.Y. dan S.R. Sianturi. (2002) Asas-Asas Hukum Pidana di Indonesia dan Penerapannya. Jakarta: Storia Grafika.

Laclau, Ernesto dan Chantal Mouffe. (2008). Hegemoni dan Strategi Sosialis: Posmarxisme dan Gerakan Sosial Baru. Yogyakarta: Resist Book.

Logeman, J.H.A. (1975). Tentang Teori suatu Hukum Tata Negara Positif. Jakarta: Ichtiar Baru-Van Hoeve.

Mertokusumo, Sudikno. (2010). Mengenal Hukum: Suatu Pengantar. Yogyakarta: Cahaya Atma Pustaka.

Pozzolini, A. (2006). Pijar-Pijar Pemikiran Gramsci. Eko P.D., penj. Yogyakarta: Resist Book.

Rahardjo, Satjipto. (2009). Hukum dan Perubahan Sosial: Suatu Tinjauan Teoretis serta Pengalaman-Pengalaman di Indonesia. Yogyakarta: Genta Publishing.

Rahayu, Derita Prapti. (2014). Budaya Hukum Pancasila. Yogyakarta: Thafa Media.

Samekto, F.X. Adji. (2008). Justice not for All: Kritik terhadap Hukum Modern dalam Perspektif Studi Hukum Kritis. Yogyakarta: Genta Press. 
Simon, Roger. (1999). Gagasan-Gagasan Politik Gramsci. Kamdani dan Imam Baehaqi, penj. Yogyakarta: Insist Press dan Pustaka Pelajar.

Soekanto, Soerjono. (2003). Pokok-Pokok Sosiologi Hukum. Jakarta: PT. RajaGrafindo Persada.

Soekanto, Soerjono dan Purnadi Purbacaraka. (1993). Sendi-Sendi Ilmu Hukum dan Tata Hukum. Bandung: Citra Aditya Bakti.

Susanto, Anthon F. (2004). Wajah Peradilan Kita: Konstruksi Sosial tentang Penyimpangan, Mekanisme Kontrol dan Akuntabilitas Peradilan Pidana. Bandung: Refika Aditama.

Takwin, Bagus. (2009). Akar-Akar Ideologi. Yogyakarta: Jalasutra.

Wignjosoebroto, Soetandyo. (2002). Hukum dalam Masyarakat: Perkembangan dan Masalah, sebuah Pengantar ke Arah Kajian Sosiologi Hukum. Malang: Bayumedia.

Wignjosoebroto, Soetandyo. (2002). Hukum: Paradigma, Metode, dan Dinamika Masalah. Jakarta: Lembaga Studi dan Advokasi Masyarakat (ELSAM) dan Perkumpulan untuk Pembaruan Hukum Berbasis Masyarakat dan Ekologi (HUMA).

\section{Jurnal}

Boothman, Derek. (2008). The Sources for Gramsci's Concept of Hegemony. Rethinking Marxism 20(2), 201-215.

Brown, Trent. (2009). Gramsci and Hegemony. Links International Journal of Socialist Renewal, http://links.org.au/node/1260

Chiang, Min-Hua. (2015). The US Hegemony, East Asia and Global Governance. Bandung: Journal of the Global South 2(1), 1-13. https://doi.org/10.1186/s40728$\underline{015-0023-9}$

Ernas, Saidin, dan Zuly Qodir. (2013). Agama dan Budaya dalam Integrasi Sosial (Belajar dari Pengalaman Masyarakat Fakfak di Propinsi Papua Barat). Jurnal Pemikiran Sosiologi 2(2), 43-58.

Gündoğan, Ercan. (2008). Conceptions of Hegemony in Antonio Gramsci's Southern Question and the Prison Notebooks. New Proposals: Journal of Marxism and Interdisciplinary Inquiry 2(1), 45-60.

Ikenberry, G. John. (2014). From Hegemony to the Balance of Power: The Rise of China and American Grand Strategy in East Asia. International Journal of Korean Unification Studies 23(2), 41-63.

Latipulhayat, Atip. (2014). Khazanah: Roscoe Pound. Padjadjaran Jurnal Ilmu Hukum 1(2), 413-424. https://doi.org/10.22304/pjih.v1n2.a12

Litowitz, Douglas. (2000). Gramsci, Hegemony, and the Law. BYU L. Rev. 2000(2), 515551.

Mattei, Ugo. (2003). A Theory of Imperial Law: A Study on U.S. Hegemony and the Latin Resistance. Indiana Journal of Global Legal Studies 10(1), 383-448. https://doi.org/10.2202/1535-1653.1088

Mawardi, Didiek R. (2015). Fungsi Hukum dalam Kehidupan Masyarakat. Jurnal Masalah-Masalah Hukum 44(3), 275-283. https://doi.org/10.14710/mmh.44.3.2015.275-283

Nugraha, Rahadian Prima. (2017). Pembaharuan UU Perkoperasian Pasca Putusan Mahkamah Konstitusi Nomor 28/PUU-XI/2013. Jurnal Legislasi Indonesia 14(1), 29-38.

Samekto, F.X. Adji. (2013). Relasi Hukum dengan Kekuasaan: Melihat Hukum dalam Perspektif Realitas. Jurnal Dinamika Hukum 13(1), 89-98. http://dx.doi.org/10.20884/1.jdh.2013.13.1.157 
Stoddart, Mark C.J. (2007). Ideology, Hegemony, Discourse: A Critical Review of Theories of Knowledge and Power. Social Thought and Research 28, 191-225.

Yusuf, Asep Warlan. (2015). Hukum dan Keadilan. Padjadjaran Jurnal Ilmu Hukum 2(1), $1-13$.

\section{Laporan Penelitian}

Anggraeni, Ricca. (2015). Mengungkap Kemampuan Cara Pembentukan Hukum Modifikasi dalam Mendukung Pembangunan Sistem Hukum Indonesia Berbasis Pancasila dan Menghadapi Tantangan di Era Global. Ujian Kualifikasi di Program Doktor Universitas Diponegoro, Semarang, 24 Juli.

Juwana, Hikmahanto. (2001). Hukum Internasional dalam Konflik Kepentingan Ekonomi Negara Berkembang dan Maju. Pidato Upacara Pengukuhan sebagai Guru Besar Tetap dalam Ilmu Hukum Internasional pada Fakultas Hukum Universitas Indonesia, Depok, 10 November.

\section{Online}

Hastuti, Oktania Tri, dan Donny Gahral Adian. (2013). Problem Subjek Hegemoni dalam Pemikiran Antonio Gramsci: Telaah Hegemoni Militer dalam Perpolitikan Indonesia. Diakses pada http://lib.ui.ac.id/naskahringkas/201604/S53383-Oktania\%20Tri\%20Hastuti 